Yegana Hakimova,

Ph.D., Associate Professor, Azerbaijan State University of Economics, Azerbaijan

ORCID ID, 0000-0001-5686-4105

email: yegana_hakimova@unec.edu.az

Yaryna Samusevych,

Ph.D., Sumy State University, Ukraine

ORCID ID, 0000-0001-7048-8388

email: iaryna.samusevych@gmail.com

Shahla Alijanova,

Azerbaijan State University of Economics, Azerbaijan

ORCID ID, 0000-0002-3115-2635

email: shahla.musaqizi@gmail.com

Esmira Guluzade,

Azerbaijan State University of Economics, Azerbaijan

ORCID ID, 0000-0002-5633-2130

email: esmira_Guluzada@unec.edu.az

Correspondence author: iaryna.samusevych@gmail.com

\title{
ECO-INNOVATION VS. ENVIRONMENTAL TAXATION: WHAT IS MORE EFFECTIVE FOR STATE BUDGET?
}

Abstract. The article is devoted to the comparative analysis of the use of environmental taxes and the introduction of environmental innovations in terms of impact on the parameters of revenues and expenditures of the state budget. The study includes 10 countries of Central and Eastern Europe (Bulgaria, Czech Republic, Hungary, Estonia, Latvia, Lithuania, Poland, Romania, Slovenia and Slovak Republic). The analysis period covers 2010-2019. Systematization of scientific research proves the importance of using different tools to ensure sustainable development and greening of the national economy. The main purpose of the study is to determine a more effective form of interaction between government and business in the process of transforming the national economy in the direction of more environmentally friendly products and technologies by economic and mathematical modeling of environmental taxes and ecoinnovation impact of budget revenues and expenditures. The calculations consist on the several stages: 1) determining the list of relevant control variables using correlation analysis, which eliminates the problem of multicollinearity; 2) determination of the model specification (fixed or random effects) using the Hausman test; 3) identification of the generalizing effects of the impact of environmental taxation and the eco-innovation index on the indicators of budget revenues and expenditures using a generalized least squares panel regression model with random effects; 4) study of the impact of the main components of environmental taxes and components of the eco-innovation index on the parameters of the state budget using panel regression modelling; 5) determination of short-term and long-term effects of the impact of environmental taxes and eco-innovations on the parameters of budget revenues and expenditures bt auto-regression distributive lag modelling. Stata 12/SE software tools were used for calculations. The study indicates the need to transform approaches to the implementation of state environmental policy. Thus, it has been proven that government incentives for the introduction of environmental innovations in the economy can be more effective than increasing the burden of environmental taxes.

Keywords: eco-innovation index, environmental taxation, government revenues, government expenditures, panel data analysis.

Introduction. The growth of national and global requirements for the competitiveness of the state requires increasing the efficiency of the organization of economic relations in both the public and private

Cite as: Hakimova, Y., Samusevych, Y., Alijanova, S., \& Guluzade, E. (2021). Eco-Innovation VS. Environmental Taxation: What is More Effective for State Budget? Marketing and Management of Innovations, 1, 312323. http://doi.org/10.21272/mmi.2021.1-24 
sectors of the economy. At the same time, the integration of goals and objectives of sustainable development in all spheres and parts of the national economy testifies to the urgency of considering the main tasks of state regulation in the context of balancing the parameters of sustainable development. In particular, it has been proven that the change in the structure of the national economy is largely related to environmental consequences (He, 2019), which indicates the need for coordination of state environmental and economic policies. At the same time, the globalization of sustainable development goals leads to an increase in the priority role of natural resource management policy in the system of state regulation of the economy (Biewendt, 2020). Hasan and Dutta (2019) argue that today resource management and environmental issues are not only the focus of scientific attention, but also the subject of considerable public interest. Environmental factors and environmental responsibility largely determine the effectiveness of companies and the creation of their market value (Boyarko and Samusevych, 2011; Taliento and Netti, 2020), which significantly affects the long-term growth of the national economy. At the same time, analyzing the factors of enterprise success, it should be noted the rapid growth of the importance of innovation, which today play the same role as financial, production and human factors (Vargas-Hernández and Rodríguez, 2018; Karaoulanis, 2018; Lyeonov et al., 2019; Rubanov et al., 2019a). It is innovative factors that ensure the transformation of the business sector and are the key to achieving global goals of sustainable development (Bilan et al., 2019; Goncharenko, 2020). At the same time, it has been proven that the development of innovations should be comprehensively consistent with other socio-economic factors (Kyrychenko et al., 2018; Kasztelnik and Brown, 2020). All this leads to the actualization of the study of tax regimes in countries with significant natural resources (Eddassi, 2020), which in conditions of tax competition should be analyzed not only in the fiscal but also in the regulatory context (Mukherjee, 2018). On the other hand, the policy of sustainable development of the state should be comprehensive, take into account national and international factors, provide long-term incentives for the implementation of advanced approaches and technologies in the real sector (Bhandari, 2019; Khan and Kishwar, 2020). Thus, in particular, it is empirically confirmed that public spending remains a tool for managing economic development, however, the controversy of the results shows their fragmentary effectiveness (Kouassi, 2018). At the same time, higher efficiency is demonstrated by targeted expenditures, in particular, green investments, the importance of which for sustainable development has been repeatedly proven (Ibragimov et al., 2019a; Pavlyk, 2020). At the same time, indirect organizational methods of influence, such as the development of internal audit and environmental innovation (Kasztelnik and Gaines, 2019; Vasylieva et al., 2020), which, inter alia, require the use of information control mechanisms and risk management, are becoming relevant (Yarovenko et al., 2021). That is why it is necessary to conduct a comparative study of various instruments of state environmental policy in order to determine the most effective forms of interaction between the state and economic agents in the context of increasing the greening of the economy, fiscal and regulatory functions of public administration.

Literature Review. Issues of sustainable development, energy efficiency and environmental security of the national economy remain central to public economic policy, which necessitates numerous studies to identify systemic relationships between the use of state regulatory instruments and study promising areas of national economy (Cebula et al., 2018). In this regard, it remains relevant to study the effectiveness of various approaches and tools of state regulation of the economy in terms of operational performance and efficiency of achieving the goals. Ibragimov et al. (2019b) revealed that environmental performance is as important for ensuring a country's competitiveness as macroeconomic stability, institutional quality, and infrastructure development.

It is substantiated that the study of economic processes should be carried out on the example of a homogeneous sample of countries, which reflects the similarity of approaches to the implementation of public economic, environmental and financial policies (Rubanov et al., 2019b; Kuzmenko et al., 2020). Therefore, to study the effectiveness of state regulatory instruments, it is first necessary to form a sample 
Y., Hakimova, Y., Samusevych, S., Alijanova, E., Guluzade. Eco-Innovation VS. Environmental Taxation: What is More Effective for State Budget?

of countries that meet the same criteria of historical and economic development, and are comparable given the specifics of economic relations.

It is proved that in the system of functioning of the national economy there is a wide set of links between economic and environmental determinants, in particular, environmental determinants largely determine the economic and food security of the country (Bilan et al., 2018; Vysochyna et al., 2020). This indicates the need for the use of tools and methods of state influence on the national economy, able to reduce harmful man-made impact, which in turn provides a comprehensive transition of the national economy to a qualitatively new stage of organization of economic processes. At the same time, studies show that there are significant relationships between the institutional environment, environmental and energy parameters (Lyulyov et al., 2021). It is determined that state support is the catalyst for economic development and systemic transformations of industry (Hrytsenko et al., 2018). That is why it can be stated that government intervention is necessary and extremely important in terms of creating incentives to change management approaches, production technologies and strategic guidelines for the development of economic entities. The main manifestation of the regulatory function of environmental tax policy is the systemic transformation of national industry in view of the reduction of extensive production with a significant level of destructive man-made impact and stimulating the transition to safer and more advanced technologies. At the same time, the change in consumer behavioral patterns indicates the creation of market incentives for enterprises to change approaches in the structure and technologies of production (Chygryn et al., 2019). That is why, given the strategic nature of sustainable development, it is necessary to consider both government regulatory initiatives, among which the most complex role belongs to environmental taxes, and internal measures of greening enterprises, among which environmental innovation has recently become widespread. It should be noted that studies of the effectiveness of tax and other economic instruments for regulating the national economy require the use of quite complex economic and mathematical tools. Thus, Levchenko et al. (2018) use fuzzy logic methods to determine the effectiveness of tax instruments in combating the shadow economy. That is why to test the research hypothesis it is advisable to use the tools of economic and mathematical modeling.

Methodology and research methods. The aim of the research is to test the hypothesis about the impact of environmental taxes and environmental innovations on the indicators of budget development of the country. The parameters of the characteristics of the forms of interaction between the state and business in ensuring the greening of the national economy are selected indicators of environmental taxation, as well as indicators of eco-innovation. Indicators of environmental taxation are: 1) Total environmental taxes,\% GDP; 2) Energy taxes, \% growth; 3) Transport taxes, \% growth; 4) Pollution taxes, $\%$ growth. The parameters of ecological innovation implementation are the general value and components of the Eco-Innovation Index, which are calculated for the countries of the European Union: 1) Eco-Innovation Index, 1-100; 2) Eco-Innovation Inputs, 1-100; 3) Eco-Innovation Activities, 1-100; 4) EcoInnovation Outputs, 1-100; 5) Eco-Innovation Socio-Economic Outcomes, 1-100; 6) Eco-Innovation Resource Efficiency Outcomes, 1-100. The resulting research variables are the parameters of revenues and expenditures of the state budget: 1) Revenue of government, excluding grants, \% GDP; 2) General government final consumption expenditure, \% GDP.To ensure the objectivity of the results, to build regression dependencies also formed a list of control variables: Industry (including construction) value added, \% GDP; Consumer price index, annual \%; Control of Corruption; Government Effectiveness.

Due to the need to make recommendations for developing countries, the sample of the study was formed from Central and Eastern European countries Bulgaria, Czech Republic, Estonia, Hungary, Latvia, Lithuania, Poland, Romania, Slovak Republic and Slovenia. The study period includes 2010-2019. In order to fulfill the task of the research it is proposed to go through the next steps: to realize correlation analysis in order to eliminate multicollinearity problem between control variables; to run Hausman test in order to clarify specification of the regression model (fixed or random effects model); to run panel data regression 
Y., Hakimova, Y., Samusevych, S., Alijanova, E., Guluzade. Eco-Innovation VS. Environmental Taxation: What is More Effective for State Budget?

analysis for the whole country sample and characterize its results; to run ARDL-model to determine longterm and short-term effects. Technically all stages of the research are realized with the help of Stata 12/SE software.

Results. Therefore, at the first stage of research it is necessary to specify the list of control variables, namely to check existence of a problem of multicollinearity. For this purpose, a correlation analysis was performed (Table 1).

Table 1. Correlation matrix of control variables

\begin{tabular}{lcccc}
\hline Variables & (1) & (2) & (3) & (4) \\
\hline (1) Control of corruption & 1.000 & & & \\
(2) Government effectiveness & 0.782 & 1.000 & & \\
(3) Consumer price index, annual \% & -0.069 & -0.194 & 1.000 & \\
(4) Industry value added, \% GDP & -0.155 & -0.212 & 0.102 & 1.000 \\
\hline
\end{tabular}

Sources: developed by the authors.

Based on the correlation analysis results it should be mentioned that there is significant correlation between two variables, namely: Control of corruption and Government effectiveness. In order to eliminate multicollinearity problem we need to exclude one or several variables. Therefore, the variable control of corruption was excluded for the further research. The next stage of the research is identification of the specification of the model that better fits the data in terms of testing the hypothesis about influence of environmental taxation or eco-innovation on country's budget indicators. Consequently, Hausman test allows identifying that better model specification is panel data regression with random effects that also allows us concluding that country specific characteristics of economic development do influence variation of its innovative development progress. Taking into account the broad statistical sample of research, generalized least square random-effects model was chosen. Moving to quantitative calculations, let's test the hypothesis about the impact of the role of environmental taxes in the formation of central budget revenues. Table 2 indicates a direct statistically significant relationship between tax revenues from environmental taxes and budget revenues, and the impact ratio is 1,194, that proves that the increase in environmental taxes not only provides a proportional increase in budget revenues, but also has a synergy effect of stimulating other budget revenues.

Table 2. Results of the regression analysis on testing the hypothesis about influence of environmental taxation on central government revenues in 10 countries in 2010-2019 (random effects model specification)

\begin{tabular}{lccclcl}
\hline \multicolumn{1}{c}{ Variable } & Coef. & St.Err. & t-value & p-value & Sig & \\
\hline Environmental taxes, \% GDP & 1.194 & 0.576 & 2.08 & 0.038 & $*$ & \\
Government effectiveness & 1.497 & 1.291 & 1.16 & 0.246 & & \\
Consumer price index, annual \% & -0.136 & 0.074 & -1.83 & 0.068 & $*$ & \\
Industry value added, \% GDP & -0.079 & 0.089 & -0.89 & 0.374 & & \\
Constant & 32.959 & 3.351 & 9.84 & 0.000 & $* * *$ & \\
Mean dependent var & \multicolumn{7}{c}{34.863} & SD dependent var & 3.771 \\
Overall r-squared & & 0.405 & Number of obs & 99.000 \\
Chi-square & & 18.184 & Prob > chi2 & 0.001 \\
R-squared within & 0.143 & R-squared between & 0.448 \\
\hline
\end{tabular}

Notes: ${ }^{* *} p<0.01,{ }^{* *} p<0.05,{ }^{*} p<0.1$.

Sources: developed by the authors.

At the same time, analyzing the impact of control variables, we should pay attention to the fact that only the Consumer price index is statistically significant, which has a disincentive effect on the formation 
Y., Hakimova, Y., Samusevych, S., Alijanova, E., Guluzade. Eco-Innovation VS. Environmental Taxation: What is More Effective for State Budget?

of budget revenues. At the same time, in general, the constructed model is adequate and statistically significant, which indicates the objectivity of the results and their compliance with real economic trends.

At the next stage, it is advisable to analyze the impact of environmental taxation parameters on budget expenditures (Table 3).

Table 3. Results of the regression analysis on testing the hypothesis about influence of environmental taxation on central government expenditures in 10 countries in 2010-2019 (random effects model specification)

\begin{tabular}{|c|c|c|c|c|c|c|c|}
\hline Variable & Coef. & St.Err. & t-value & $p$-value & Lowest $95 \%$ & Highest $95 \%$ & Sig \\
\hline $\begin{array}{l}\text { Environmental taxes, \% } \\
\text { GDP }\end{array}$ & 0.232 & 0.309 & 0.75 & 0.453 & -0.374 & 0.838 & \\
\hline Government effectiveness & -0.746 & 0.662 & -1.13 & 0.260 & -2.043 & 0.551 & \\
\hline $\begin{array}{l}\text { Consumer price index, } \\
\text { annual } \%\end{array}$ & 0.060 & 0.043 & 1.41 & 0.159 & -0.023 & 0.144 & \\
\hline $\begin{array}{l}\text { Industry value added, \% } \\
\text { GDP }\end{array}$ & -0.169 & 0.048 & -3.53 & 0.000 & -0.263 & -0.075 & $* * *$ \\
\hline Constant & 22.573 & 1.764 & 12.80 & 0.000 & 19.115 & 26.031 & $* * *$ \\
\hline Mean dependent var & & \multicolumn{2}{|c|}{18.196} & \multicolumn{2}{|c|}{ SD dependent var } & 1.635 & \\
\hline Overall r-squared & & \multicolumn{2}{|c|}{0.007} & \multicolumn{2}{|c|}{ Number of obs } & 100.000 & \\
\hline Chi-square & & \multicolumn{2}{|c|}{15.381} & \multicolumn{2}{|c|}{ Prob > chi2 } & 0.004 & \\
\hline R-squared within & & \multicolumn{2}{|c|}{0.221} & \multicolumn{2}{|c|}{ R-squared between } & 0.030 & \\
\hline
\end{tabular}

The obtained results indicate the fact that the growth of the burden of environmental taxation does not provide an increase in government spending on the national economy (the relationship between the indicators was statistically insignificant). At the same time, attention should be payed on the fact that the growth of value added in industry leads to a reduction in budget expenditures, which reflects the positive effects of private sector development and structural transformation in the economy.

The next stage of the study is the analysis of the impact of structural components of environmental taxation on revenues and expenditures of the state budget. Therefore, the data presented in Table 4 shows the impact of the annual growth of certain types of environmental taxes on budget indicators. Importantly, this effect was statistically insignificant for almost all constructed models.

Table 4. Results of the regression analysis on testing the hypothesis about influence of different components of environmental taxation on central government revenues and expenditures in 10 countries in 2010-2019 (random effects model specification)

\begin{tabular}{lcccccc}
\hline \multirow{2}{*}{\multicolumn{1}{c}{ Variable }} & \multicolumn{3}{c}{ Revenues } & \multicolumn{3}{c}{ Expenditures } \\
\cline { 2 - 7 } & Model 1 & Model 2 & Model 3 & Model 4 & Model 5 & Model 6 \\
\hline Energy taxes, \% growth & 0.008 & & & -0.009 & & \\
Transport taxes, \% growth & & -0.014 & & & -0.003 & \\
Pollution taxes, \% growth & & & 0.000 & & & $0.005^{* *}$ \\
Government effectiveness & 1.777 & 1.595 & 1.745 & -0.194 & 0.424 & -0.794 \\
Consumer price index, annual \% & $-0.174^{* *}$ & $-0.178^{* *}$ & $-0.178^{* *}$ & 0.042 & 0.050 & 0.035 \\
Industry value added, \% GDP & -0.149 & $-0.173^{*}$ & -0.147 & $-0.206^{* * *}$ & $-0.162^{* * *}$ & $-0.229^{* * *}$ \\
Constant & $38.014^{* * *}$ & $38.900^{* * *}$ & $38.023^{* * *}$ & $23.759^{* * *}$ & $22.107^{* * *}$ & $24.749^{* * *}$ \\
Chi-square & 15.803 & 18.900 & 15.358 & 20.960 & 16.084 & 31.343 \\
Prob > chi2 & 0.003 & 0.001 & 0.004 & 0.000 & 0.003 & 0.000 \\
\hline
\end{tabular}

Notes: ${ }^{* * *} p<0.01,{ }^{* *} p<0.05,{ }^{*} p<0.1$.

Sources: developed by the authors. 
Y., Hakimova, Y., Samusevych, S., Alijanova, E., Guluzade. Eco-Innovation VS. Environmental Taxation: What is More Effective for State Budget?

At the same time, it can be stated that the increase in pollution taxes causes an additional increase in budget expenditures, which indicates the fact that an ecologically inefficient economy needs much more state support than an economy with advanced environmentally friendly technologies that do not create significant environmental pollution. environment and, accordingly, do not lead to an increase in environmental taxes. At the same time, the impact of control variables was similar to the previously obtained results, which confirms the previously obtained conclusions on catalysts and inhibitors of fiscal policy. The next hypothesis of the study is to test the impact of the implementation of eco-innovations on budget development indicators. Table 5 shows the results of assessing the impact of the generalized ecoinnovation index, which reflects the country's progress in implementing eco-innovation in relation to other countries of the European Union, on the level of budget revenues. Note that the obtained results have a high level of statistical significance. Thus, the growth of the general assessment of the eco-innovation progress of the country per unit is on average associated with the growth of budget revenues by $0.035 \%$ of GDP. At the same time, it should be noted that, similarly to environmental taxation, the indicator that restrains the expected effect was the consumer price index.

Table 5. Results of the regression analysis on testing the hypothesis about influence of ecoinnovations on central government revenues in 10 countries in 2010-2019 (random effects model specification

\begin{tabular}{|c|c|c|c|c|c|c|c|}
\hline Variable & Coef. & St.Err. & $\mathrm{t}$-value & $p$-value & Lowest $95 \%$ & Highest $95 \%$ & Sig \\
\hline Eco-Innovation Index & 0.035 & 0.012 & 2.95 & 0.003 & 0.012 & 0.059 & $* * *$ \\
\hline Government effectiveness & 0.920 & 1.294 & 0.71 & 0.477 & -1.617 & 3.457 & \\
\hline Consumer price index, annual \% & -0.179 & 0.074 & -2.43 & 0.015 & -0.323 & -0.035 & ** \\
\hline Industry value added, \% GDP & -0.058 & 0.087 & -0.66 & 0.508 & -0.228 & 0.113 & \\
\hline Constant & 33.782 & 2.975 & 11.35 & 0.000 & 27.951 & 39.614 & $* * *$ \\
\hline Mean dependent var & \multicolumn{5}{|c|}{34.863 SD dependent var } & \multicolumn{2}{|l|}{3.771} \\
\hline Overall r-squared & \multicolumn{5}{|c|}{0.261 Number of obs } & \multicolumn{2}{|l|}{99.000} \\
\hline Chi-square & \multicolumn{5}{|c|}{ 23.131 Prob > chi2 } & \multicolumn{2}{|l|}{0.000} \\
\hline R-squared within & & & \multicolumn{3}{|c|}{0.197 R-squared between } & \multicolumn{2}{|l|}{0.301} \\
\hline
\end{tabular}

Sources: developed by the authors.

Along with this, it should be noted that the indicators of implementation of eco-innovation are not only stimulators of budget revenue growth, but also provide a reduction in budget expenditures, as evidenced by the results presented in Table 6 .

Table 6. Results of the regression analysis on testing the hypothesis about influence of ecoinnovations on central government expenditures in 10 countries in 2010-2019 (random effects model specification)

\begin{tabular}{|c|c|c|c|c|c|c|c|}
\hline Variable & Coef. & St.Err. & t-value & $p$-value & Lowest $95 \%$ & Highest $95 \%$ & Sig \\
\hline Eco-Innovation Index & -0.016 & 0.007 & -2.47 & 0.013 & -0.029 & -0.003 & ** \\
\hline Government effectiveness & -0.202 & 0.665 & -0.30 & 0.762 & -1.506 & 1.103 & \\
\hline Consumer price index, annual \% & 0.070 & 0.041 & 1.70 & 0.090 & -0.011 & 0.150 & * \\
\hline Industry value added, \% GDP & -0.202 & 0.046 & -4.34 & 0.000 & -0.293 & -0.111 & $* * *$ \\
\hline Constant & 24.74 & 1.534 & 16.13 & 0.000 & 21.735 & 27.746 & *** \\
\hline Mean dependent var & \multirow{2}{*}{\multicolumn{5}{|c|}{$\begin{array}{l}\text { 18.196 SD dependent var } \\
0.005 \text { Number of obs }\end{array}$}} & \multicolumn{2}{|c|}{1.635} \\
\hline Overall r-squared & & & & & & \multicolumn{2}{|c|}{100.000} \\
\hline Chi-square & \multicolumn{5}{|c|}{ 23.172 Prob > chi2 } & & \\
\hline R-squared within & \multicolumn{5}{|c|}{0.290 R-squared between } & \multicolumn{2}{|c|}{0.026} \\
\hline
\end{tabular}

Notes: ${ }^{* * *} p<0.01,{ }^{* *} p<0.05,{ }^{*} p<0.1$.

Sources: developed by the authors. 
Comparing the results of this stage of the study, we can note more high complexity of connections of parameters of eco-innovations with budgetary indicators, than it was established earlier for parameters of ecological taxation. In this regard, it can be stated that at the present stage it is more effective for the state budget policy not to increase environmental taxation, but to create incentives for the widespread implementation of environmentally innovative approaches in the activities of economic agents. At the same time, a necessary stage of the study is also the analysis of the structural components of the eco-innovation index in order to identify the most effective channels for the impact of eco-innovation progress on improving the effectiveness of fiscal policy. Thus, the results of assessing the impact of subcomponents of the ecoinnovation index on budget revenues are shown in Table 7.

Table 7. Results of the regression analysis on testing the hypothesis about influence of different dimensions of eco-innovations on central government revenues in 10 countries in 2010-2019 (random effects model specification)

\begin{tabular}{lccccc}
\hline \multicolumn{1}{c}{ Variable } & Model 1 & Model 2 & Model 3 & Model 4 & Model 5 \\
\hline Eco-Innovation Inputs & $-0.016^{*}$ & & & & \\
Eco-Innovation Activities & & $0.020^{* *}$ & & & \\
Eco-Innovation Outputs & & & 0.004 & & \\
Eco-Innovation Socio-Economic & & & & & \\
Outcomes & & & & \\
Eco-Innovation Resource & & & & \\
Efficiency Outcomes & 1.981 & 0.952 & 1.658 & 1.500 & 2.002 \\
Government effectiveness & $-0.205^{* *}$ & $-0.235^{* * *}$ & $-0.225^{* * *}$ & $-0.168^{* *}$ & $-0.213^{* * *}$ \\
Consumer price index, annual \% & 0.029 & -0.020 & -0.009 & 0.043 & -0.022 \\
Industry value added, \% GDP & $33.673^{* * *}$ & $33.559^{* * *}$ & $34.009^{* * *}$ & $31.054^{* * *}$ & $34.065^{* * *}$ \\
Constant & 17.046 & 21.459 & 14.287 & 18.548 & 13.986 \\
Chi-square & 0.002 & 0.000 & 0.006 & 0.001 & 0.007 \\
Prob > chi2 & & & & & \\
\hline
\end{tabular}

Notes: ${ }^{* * *} p<0.01,{ }^{* *} p<0.05,{ }^{*} p<0.1$.

Sources: developed by the authors.

The results show that the growth of Eco-Innovation Inputs (R\&D expenditures and personnel, green investments) leads to a reduction in budget revenues, which is quite natural, because in the early stages of investment and innovation processes costs always significantly exceed the result. Instead, effective catalysts for growth of budget revenues should be considered Eco-Innovation Activities (implementation of ecologically efficient products and technologies, certification of the quality of production) and EcoInnovation Socio-Economic Outcomes (growth in environmentally friendly export of production, value added and employment). At the same time, other parameters (Eco-Innovation Outputs, Eco-Innovation Resource Efficiency Outcomes) do not have a statistically significant direct impact on the dynamics of budget revenues. Thus, it can be noted that even within the short-term period eco-innovation implementation has a positive effect not only on quantitative and qualitative indicators of economic development, but also provides accumulation of additional budget revenues by increasing economic agents and increasing their economic efficiency. On the other hand, calculation results presented by Table 8 show that only two subcomponents of the eco-innovation index provide a statistically significant reduction in budget expenditures. Thus, the growth of the general indicator of the results of the implementation of eco-innovation (Eco-Innovation Outputs) per unit is associated with a reduction in budget expenditures by an average of $0.011 \%$ of GDP. At the same time, larger budget savings are provided by the growth of such a sub-index as Eco-Innovation Socio-Economic Outcomes - an average of $0.021 \%$ of GDP. Thus, it can be stated that the growth of production and sales of eco-innovative products has a broad positive 
Y., Hakimova, Y., Samusevych, S., Alijanova, E., Guluzade. Eco-Innovation VS. Environmental Taxation: What is More Effective for State Budget?

impact on improving the efficiency of budget policy, while ensuring increased budget revenues and reduced budget expenditures.

Table 8. Results of the regression analysis on testing the hypothesis about influence of different dimensions of eco-innovations on central government expenditures in 10 countries in 2010-2019 (random effects model specification)

\begin{tabular}{lccccc}
\hline \multicolumn{1}{c}{ Variable } & Model 1 & Model 2 & Model 3 & Model 4 & Model 5 \\
\hline Eco-Innovation Inputs & 0.005 & & & & \\
Eco-Innovation Activities & & 0.003 & & & \\
Eco-Innovation Outputs & & & $-0.011^{* * *}$ & & \\
Eco-Innovation Socio-Economic & & & & $-0.021^{* *}$ & \\
Outcomes & & & & -0.001 \\
Eco-Innovation Resource & & & & & \\
Efficiency Outcomes & -0.146 & -0.342 & 0.684 & -0.068 & 0.345 \\
Government effectiveness & 0.036 & 0.038 & $0.073^{*}$ & 0.011 & 0.045 \\
Consumer price index, annual \% & $-0.122^{* *}$ & $-0.115^{*}$ & $-0.135^{* *}$ & $-0.151^{* *}$ & $-0.098^{*}$ \\
Industry value added, \% GDP & $21.264^{* * *}$ & $21.299^{* * *}$ & $21.837^{* *}$ & $23.360^{* * *}$ & $20.628^{* * *}$ \\
Constant & 4.582 & 4.045 & 23.998 & 9.799 & 3.802 \\
Chi-square & 0.333 & 0.400 & 0.000 & 0.044 & 0.433 \\
Prob > chi2 & & & &
\end{tabular}

Notes: ${ }^{* * *} p<0.01,{ }^{* *} p<0.05,{ }^{*} p<0.1$.

Sources: developed by the authors.

At the same time, an important task of the study is to identify time horizons for maximizing the impact of environmental taxes and eco-innovations on the parameters of fiscal policy. To this end, an autoregressive distributed lag model was constructed (Table 9).

Table 9. Results of the regression analysis on testing the hypothesis about influence of different dimensions of eco-innovations on central government budget indicators in 10 countries in 20102019 (autoregressive distributed lag model)

\begin{tabular}{|c|c|c|c|c|c|c|c|}
\hline Effects & Variable & Coef. & St.Err. & t-value & $p$-value & $\begin{array}{l}\text { Lowest } \\
95 \%\end{array}$ & $\begin{array}{l}\text { Highest } \\
95 \%\end{array}$ \\
\hline \multicolumn{8}{|c|}{ Central government revenues } \\
\hline $\begin{array}{l}\text { Long- } \\
\text { term }\end{array}$ & $\begin{array}{l}\text { Environmental taxes, \% } \\
\text { GDP }\end{array}$ & $191.922^{* * *}$ & 51.881 & 3.70 & 0.000 & 90.236 & 293.608 \\
\hline effects & Eco-Innovation Index & $0.331^{* * *}$ & 0.091 & 3.63 & 0.000 & 0.152 & 0.510 \\
\hline $\begin{array}{l}\text { Short- } \\
\text { term }\end{array}$ & $\begin{array}{l}\text { Environmental taxes, \% } \\
\text { GDP }\end{array}$ & 17.126 & 13.905 & 1.23 & 0.218 & -10.126 & 44.379 \\
\hline effects & Eco-Innovation Index & 0.018 & 0.022 & 0.82 & 0.415 & -0.025 & 0.062 \\
\hline \multicolumn{8}{|c|}{ Central government expenditures } \\
\hline $\begin{array}{l}\text { Long- } \\
\text { term }\end{array}$ & $\begin{array}{l}\text { Environmental taxes, \% } \\
\text { GDP }\end{array}$ & $3.078^{* *}$ & 1.460 & 2.11 & 0.035 & 0.216 & 5.941 \\
\hline effects & Eco-Innovation Index & $0.019^{* * *}$ & 0.002 & 8.11 & 0.000 & 0.014 & 0.024 \\
\hline $\begin{array}{l}\text { Short- } \\
\text { term }\end{array}$ & $\begin{array}{l}\text { Environmental taxes, \% } \\
\text { GDP }\end{array}$ & 0.369 & 0.491 & 0.75 & 0.452 & -0.593 & 1.332 \\
\hline effects & Eco-Innovation Index & $-0.006^{* *}$ & 0.003 & -1.97 & 0.048 & -0.013 & 0.000 \\
\hline
\end{tabular}


Y., Hakimova, Y., Samusevych, S., Alijanova, E., Guluzade. Eco-Innovation VS. Environmental Taxation: What is More Effective for State Budget?

The results of the calculations indicate the fact that in the short term, neither environmental taxes nor environmental innovations provide a positive impact on the growth of budget revenues. In addition, in the long run, both studied indicators have a statistically significant and large-scale quantitative impact on improving the efficiency of fiscal policy. On the other hand, in the long run, both the growth of environmental taxes and the implementation of eco-innovation determine additional budget expenditures, while in the short run, the eco-innovation index shows statistically significant effects of budget savings. At the same time, large-scale indicators of long-term impact on budget revenues and expenditures show that in the long run, the growth of environmental taxation and intensification of eco-innovation progress provide much higher indicators of additional budget revenues than budget expenditures they need. Thus, an indepth analysis of the components of environmental taxation and implementation of eco-innovations shows that at the present stage a more effective form of interaction between government and business is not environmental taxation, but the introduction of innovative approaches to doing business. Thus, despite the regulatory function, the growth of the tax burden on environmental taxation does not always lead to the renewal of production technologies of enterprises and the implementation of other actions aimed at minimizing the tax base. At the same time, additional budget revenues received from the growth of environmental taxes are almost always accompanied by an increase in budget expenditures associated with the inefficiency of the national economy, which can not only lead to full expenditure of additional revenues, but in some cases, to demand more expenses than can be provided at the expense of the received tax receipts.

Conclusions. Nowadays methods and tools to achieve the goals of sustainable development remain in the center of scientific attention and are important for the tasks of public policy. The purpose of the study was to identify more effective tools for ensuring the environmental development of the country in the context of improving the efficiency of public budget policy. Calculations conducted for 10 countries of the European Union showed the following results:

- increasing the level of environmental taxation provides growth of budget revenues, however, has no statistically significant impact on the parameters of budget expenditures, while the growth of the EcoInnovation Index provides a comprehensive increase in fiscal policy by increasing revenues and saving budget expenditures;

- the growth of different environmental taxes does not have a statistically significant impact on the growth of budget revenues, while the growth of transport taxes provides an increase in budget expenditures;

- increasing the fiscal efficiency of budget policy provides growth of such components of the EcoInnovation Index as Eco-Innovation Activities and Eco-Innovation Socio-Economic Outcomes, while the parameters capable of saving budget resources were such components as Eco-Innovation Outputs and Eco -Innovation Socio-Economic Outcomes;

- in the long run, both environmental taxation and eco-innovation provide growth in budget revenues, which is accompanied by additional budget expenditures, while in the short term, only environmental innovations have a statistically significant impact on fiscal policy parameters, saving budget expenditures.

The study indicates the need to transform approaches to the implementation of state environmental policy. Thus, it has been proven that government incentives for the introduction of environmental innovations in the economy can be more effective than increasing the burden of environmental taxes. Given the fact that the state has no direct influence on decisions on the implementation of eco-innovation, an important task of state environmental policy should be to create incentives for economic entities to develop and implement eco-innovation.

Funding: This paper was supported by the Ministry of Education and Science of Ukraine, and performed the results of the projects «Structural-functional multiplex model of ecological tax system 
building in Ukraine in the context of national security» (registration number 0119U100759) and «Data Mining for Countering Cyber Fraud and Money Laundering in the Context of Digitalization of the Financial Sector of the Ukrainian Economy» (registration number 0121U100467).

Author Contributions: conceptualization and methodology, Y. H. and Y. S.; software, S. A.; validation, S. A. and E. G.; formal analysis and investigation, Y.H., Y.S. and E. G.; resources, data curation, writing-original draft preparation, writing-review and editing, Y.H., Y.S., S. A., and E. G.; visualization, E. G.; supervision, Y. H., Y. S., S. A., and E. G.; project administration, S. A.

\section{References}

Akimova, L. M., Akimov, O. O., \& Liakhovich, O. O. (2017). State regulation of foreign economic activity. Scientific bulletin of Polissia, 1(4 (12)), 98-103.. [Google Scholar]

Akimova, L., Akimov, O., Mihus, I., Koval, Y., \& Dmitrenko, V. (2020). Improvement of the methodological approach to assessing the impact of public governance on ensuring the economic security of the state. Financial and credit activity: problems of theory and practice, 4(35), 180-190. [Google Scholar]

Baranovskyi, O. I. (2020). Regulation of functional and structural transformational processes in the financial sector. Financial and credit activity: problems of theory and practice, 1(32), 292-306. [Google Scholar] [CrossRef]

Bhandari, M. P. (2019). Sustainable Development: Is This Paradigm The Remedy of All Challenges? Does Its Goals Capture The Essence of Real Development and Sustainability? With Reference to Discourses, Creativeness, Boundaries and Institutional Architecture. SocioEconomic Challenges, 3(4), 97-128. [Google Scholar] [crossRef]

Biewendt, M. (2020). Sustainable Development: A Quantitative Analysis Regarding the Impact of Resource Rents on State Welfare from 2002 to 2017. SocioEconomic Challenges, 4(4), 119-131. [Google Scholar] [CrossRef]

Bilan, Y., Lyeonov, S., Stoyanets, N., \& Vysochyna, A. (2018). The impact of environmental determinants of sustainable agriculture on country food security. International Journal of Environmental Technology and Management, 21(5-6), 289-305. [Google Scholar] [CrossRef]

Bilan, Y., Samusevych, Y., \& Vysochyna, A. (2019). Drivers and Inhibitors of Entrepreneurship Development in Central and Eastern European Countries. Education Excellence and Innovation Management through Vision 2020: Proceedings of the 33rd International-Business-Information-Management-Association (IBIMA) Conference. P. 2536-2547. [Google Scholar]

Boyarko, I. M., \& Samusevych, Y. V. (2011). Role of intangible assets in company's value creation. Actual Problems of Economics, (117), 86-94.

Chygryn, O., Pimonenko, T., Bilan, S., \& Starchenko, L. (2019). Digital Marketing for Green Goods Promotion: Modern Trends in Entrepreneurship. Vplyv Industry 4.0 na Tvorbu Pracovnych Miest 2019: Proceedings of the International Scientific Conference on The Impact of Industry 4.0 on Job Creation, p. 160-166. Retrieved from [Link]

Eddassi, H. (2020). Fiscal Regime and Tax Policy in Resource-Rich Countries In The Process Of Globalization: Literature Review. SocioEconomic Challenges, 4(2), 67-77. [Google Scholar] [CrossRef]

Girchenko, T. D., Panchenko, O.V. (2020). Research on the practical aspects of the providing efficiency of marketing

communications' bank. Financial and credit activity-problems of theory and practice, 3. P. 13-22. [CrossRef]

Hasan, S., \& Dutta, P. (2019). Coverage of Environmental Issues in Local Dailies of Chattogram Centering World Environment Day. SocioEconomic Challenges, 3(4), 63-71. [Google Scholar] [CrossRef]

He, S. (2019). The Impact of Trade on Environmental Quality: A Business Ethics Perspective and Evidence from China. Business Ethics and Leadership, 3(4), 43-48. [Google Scholar] [CrossRef]

Hrytsenko, L. L., Roienko, V. V., \& Boiarko, I. M. (2018). Institutional background of the role of state in investment processes activation. Financial and credit activity: problems of theory and practice, 1(24), 338-344. [Google Scholar] [CrossRef]

Ibragimov, Z., Lyeonov, S., \& Pimonenko, T. (2019a). Green investing for SDGS: EU experience for developing countries. Economic and Social Development: Book of Proceedings, 867-876. [Google Scholar]

Ibragimov, Z., Vasylieva, T., \& Lyulyov, O. (2019b). The National Economy Competitiveness: Effect of Macroeconomic Stability, Renewable Energy on Economic Growth. Economic and Social Development (ESD 2019): Proceedings of the 37th International Scientific Conference on Economic and Social Development - Socio Economic Problems of Sustainable Development, 878-887. [Google scholar]

Karaoulanis, A. (2018). Strategic Transformation and Innovation towards Blue Ocean Creation in a Changing Corporate Reality. Business Ethics and Leadership, 2(2), 49-55. [Google Scholar] [CrossRef]

Karpa, M. I., Akimova, L. M., Akimov, O. O., Serohina, N., Oleshko, O., \& Lipovska, N. (2021). Public administration as a systemic phenomenon in society. AD ALTA: Journal of interdisciplinary research, (11), 56-62. [Google Scholar]

Kashintseva, V., Strielkowski, W., Streimikis, J., \& Veynbender, T. (2018). Consumer attitudes towards industrial CO2 capture and storage products and technologies. Energies, 11(10), 2787. [CrossRef] 
Y., Hakimova, Y., Samusevych, S., Alijanova, E., Guluzade. Eco-Innovation VS. Environmental Taxation: What is More Effective for State Budget?

Kasztelnik, K., \& Brown, D. (2020). The Observational Socio-Economic Study and Impact on the International Innovative Leadership in the United States. SocioEconomic Challenges, 4(4), 63-94. [Google Scholar] [CrossRef]

Khan, M. A., \& Kishwar, A. (2020). Natural Resource Rent and Financial Development Nexuses in Bangladesh: The Role of Institutional Quality. Financial Markets, Institutions and Risks, 4(2), 108-114. [Google Scholar] [CrossRef]

Kouassi, K. B. (2018). Public Spending and Economic Growth in Developing Countries: a Synthesis. Financial Markets, Institutions and Risks, 2(2), 22-30. [Google Scholar] [CrossRef]

Kuzmenko, O., Vasylieva, T., Vojtovic, S., Chygryn, O., \& Snieska, V. (2020). Why Do Regions Differ In Vulnerability To Covid19? Spatial Nonlinear Modeling Of Social And Economic Patterns. Economics \& Sociology, 13(4), 318-340. [Google Scholar] [CrossRef]

Kyrychenko, K. I., Samusevych, Y. V., Liulova, L. Y., \& Bagmet, K. (2018). Innovations in country's social development level estimation. Marketing and Management of Innovations, 2, 113-128. [Google Scholar] [CrossRef]

Levchenko, V., Kobzieva, T., Boiko, A., \& Shlapko, T. (2018). Innovations in Assessing the Efficiency of the Instruments for the National Economy De-Shadowing: the State Management Aspect. Marketing and Management of Innovations, 4, 361-371. [Google Scholar] [CrossRef]

Lisin, E., Shuvalova, D., Volkova, I., \& Strielkowski, W. (2018). Sustainable development of regional power systems and the consumption of electric energy. Sustainability, 10(4), 1111. [CrossRef]

Lyeonov, S., Bilan, Y., Rubanov, P., \& Grencikova, A. (2019). Countries Financial Development and Digital Readiness as Determinants of Financial Sector Innovativeness. Vision 2025: Education Excellence and Management of Innovations through Sustainable Economic Competitive Advantage: Proceedings of the 34th International-Business-Information-ManagementAssociation (IBIMA) Conference. P. 13604-13619.

Lyulyov, O., Pimonenko, T., Kwilinski, A., Dzwigol, H., Dzwigol-Barosz, M., Pavlyk, V., \& Barosz, P. (2021). The Impact of the Government Policy on the Energy Efficient Gap: The Evidence from Ukraine. Energies, 14(2), 373. [Google Scholar] [CrossRef]

Mukherjee, S. (2018). Cross Country Tax Competition and its Impact on Multinational Corporations - a Theoretical Reexamination. Financial Markets, Institutions and Risks, 2(1), 97-104. [Google Scholar]

Pavlyk, V. (2020). Assessment of green investment impact on the energy efficiency gap of the national economy. Financial Markets, Institutions and Risks, 4(1), 117-123. [Google Scholar] [CrossRef

Rausser, G., Strielkowski, W., \& Štreimikienè, D. (2018). Smart meters and household electricity consumption: A case study in Ireland. Energy \& Environment, 29(1), 131-146. [CrossRef]

Rubanov, P., Lyeonov, S., Bilan, Y., \& Lyulyov, O. (2019a). The Fintech Sector as a Driver of Private Entrepreneurship Development in Time of Industry 4.0. Vplyv Industry 4.0 na Tvorbu Pracovnych Miest 2019: Proceedings of the International Scientific Conference on The Impact of Industry 4.0 on Job Creation. P. 319-327. Retrieved from [Link]

Rubanov, P., Vaylieva, T., Lyeonov, S., \& Pokhylko, S. (2019). Cluster analysis of development of alternative finance models depending on the regional affiliation of countries. Business and Economic Horizons (BEH), 15(1). [Google Scholar]

Taliento, M., \& Netti, A. (2020). Corporate Social/Environmental Responsibility and Value Creation: Reflections on a Modern Business Management Paradigm. Business Ethics and Leadership, 4(4), 123-131. [CrossRef]

Vargas-Hernández, J. G., \& Rodríguez, C. R. F. (2018). Leadership Styles as a Challenge to Generate Innovation Environments in the Companies of the 21st Century. Business Ethics and Leadership, 2(4), 64-73. [Google Scholar] [CrossRef]

Vasylieva, T., Kuzmenko, O., Rashid, M. N., Vojtovic, S., Kascha, M., \& Lieonov, H. (2020). Innovations in government management of the healthcare system: forecasting of COVID-19 consequences in social, investment and business development. Marketing and Management of Innovations, 4, 11-25. [Google Scholar] [CrossRef]

Vovchak, O. D., Senyshch, P. M., \& Melnyk, T. V. (2019). «Purging» of the banking system: impact on the key performance indicators of banks. Financial and credit activity: problems of theory and practice, 1(28), 16-25. [Google Scholar] [CrossRef]

Vysochyna, A., Stoyanets, N., Mentel, G., \& Olejarz, T. (2020). Environmental determinants of a country's food security in shortterm and long-term perspectives. Sustainability, 12(10), 4090. [Google Scholar] [CrossRef

Yarovenko, H., Bilan, Y., Lyeonov, S., \& Mentel, G. (2021). Methodology for assessing the risk associated with information and knowledge loss management. Journal of Business Economics and Management, 22(2), 369-387. [Google Scholar] [CrossRef]

Zahorskyi, V. S., Lipentsev, A. V., Yurystovska, N. Y., Mazii, N. H., \& Akimov, O. O. (2019). Financial and administrative aspects of small business development in Ukraine. Financial and credit activity: problems of theory and practice, 3(30), 351-360. [Google Scholar]

Єгана Хакімова, Азербайджанський державний економічний університет, Азербайджан

Ярина Самусевич, к.е.н, Сумський державний університет, Україна

Шахла Аліджанова, Азербайджанський державний економічний університет, Азербайджан

Есміра Гулузаде, Азербайджанський державний економічний університет, Азербайджан

Екологічні інновації проти екологічного оподаткування: що ефективніше для державного бюджету?

Статтю присвячено порівняльному аналізу використання екологічних податків та впровадження екологічних інновацій з точки зору впливу на параметри доходів і витрат бюджету держави. Дослідження включає 10 країн Центральної і Східної Європи (Болгарія, Чеська Республіка, Угорщина, Естонія, Латвія, Литва, Польща, Румунія, Словенія, Словацька Республіка). Період аналізу охоплює 2010-2019рр. Систематизація наукових досліджень доводить важливість застосування інструментів 
Y., Hakimova, Y., Samusevych, S., Alijanova, E., Guluzade. Eco-Innovation VS. Environmental Taxation: What is More Effective for State Budget?

забезпечення сталого розвитку та екологізації національної економіки. Основна мета дослідження полягає у визначенні більш ефективної форми взаємодії держави та бізнесу в процесі забезпечення трансформацій національної економіки в напрямку більш екологічно безпечних продуктів та технологій шляхом економіко-математичного моделювання впливу екологічних податків та еко-інновацій на показники бюджетних доходів та витрат. Розрахунки передбачають застосування декількох етапів: 1) визначення переліку релевантних контрольних змінних за допомогою кореляційного аналізу, що забезпечує усунення проблеми мультиколінеарності; 2) визначення специфікації моделі (з фіксованими або випадковими ефектами) за допомогою тесту Хаусмана; 3) ідентифікація узагальнюючих ефектів впливу екологічного оподаткування та індексу еко-інновацій на показники бюджетних доходів та витрат за допомогою узагальненої панельної регресійної моделі з випадковими ефектами; 4) дослідження впливу основних складових екологічних податків та компонентів індексу екоінновацій на параметри державного бюджету за домогою панельного регресійного моделювання; 5) визначення короткострокових та довгострокових ефектів впливу екологічних податків та еко-інновацій на параметри бюджетних доходів та витрат за допомогою авторегресійної моделі з розподіленим лагом. Для проведення розрахунків використано інструментарій програмного забезпечення Stata 12/SE. Проведене дослідження вказує на необхідність трансформації підходів до реалізації державної екологічної політики. Так, доведено, що більш ефективними можуть стати державні стимули для впровадження в економіці екологічних інновацій, аніж підвищення навантаження з екологічних податків.

Ключові слова: індекс еко-інновацій, екологічне оподаткування, державні доходи, державні витрати, аналіз панельних даних. 